\title{
The Effect of Different Fluxes on Thermal Behavior of Floor Tile Glazes
}

\author{
Z.B. OzTURK ${ }^{a, *}$, B. YILDIZ ${ }^{b}$ \\ ${ }^{a}$ Nevşehir HacıBektaş Veli University, Faculty of Engineering and Architecture, \\ Department of Metallurgical and Materials Engineering, Nevşehir, Turkey \\ ${ }^{b}$ Yurtbay Seramik, Oklubalı Köyü İnönü/Eskişehir, Turkey
}

\begin{abstract}
Nepheline-syenite is a fluxing agent used in sanitary ware, electrical porcelain and chinaware bodies, in order to reduce firing temperature and to increase the alkali level in the liquid glassy phase. Compared to pure feldspars, the advantages coming from the use of nepheline-syenite are: (i) the content of potassium and sodium is higher and (ii) the melting temperature is generally lower than that of potassium-feldspar, which always contains other phases, such as quartz, which shift the melting point to higher temperatures. The content of $\mathrm{Al}_{2} \mathrm{O}_{3}$ is high and the content of $\mathrm{SiO}_{2}$ is lower in nepheline-syenite with respect to feldspars (considering that in feldspar $\mathrm{Al}_{2} \mathrm{O}_{3} / \mathrm{SiO}_{2}$ is about 0.2 , whereas in nepheline $\mathrm{Al}_{2} \mathrm{O}_{3} / \mathrm{SiO}_{2}$ is 0.5 ). The aim of this study is to compare the influence of the nepheline-syenite and feldspars on the thermal behavior of the floor tile glazes. For this aim; several formulations were prepared with industrial raw materials. After applying the glazes on bodies; the compositions were fired in industrial floor tile kiln $\left(\approx 1190^{\circ} \mathrm{C}\right.$, for $\left.43 \mathrm{~min}\right)$. Thermal behaviors of glazes were measured by hot stage microscope and the crystalline phases were identified by X-ray diffraction. Color properties and glossiness were measured for comparing the aesthetic characteristics.
\end{abstract}

DOI: 10.12693/APhysPolA.127.1183

PACS: 81.05.Je

\section{Introduction}

Ceramic tile coatings are of prominent importance in building applications because of improved properties, namely, high resistance to wear, high surface hardness and chemical resistance, decorative appearance. During firing of ceramic tiles different physical-chemical processes occur directly on the surface of the ceramic body, such as decomposition of the raw materials, polymorphic transformations, melting and crystallization of phases and others. For this reason, the quality of the surface and the formation process largely depend on chemical compositions of glaze and the firing regime [1]. Recently, in the production of ceramic tiles the firing process is extremely rapid usually less than $30 \mathrm{~min}$ at $\approx 1200{ }^{\circ} \mathrm{C}[2]$. In this connection, feldspars, minerals with high alkali content, are widely used as fluxing agent in compositions of the tile coatings. The most popular fluxes used in tile industries are sodium and potassium feldspars [3]. The type and content of alkali oxides are the main factors in fluxing behavior of feldspars [4]. Nepheline is an another fluxing agent but it enters in the formulation of different products such as sanitary ware, electrical porcelain, glass ceramics and chinaware bodies due to its property of reducing firing temperature and increasing the alkali level in the liquid phase $[5,6]$. Nepheline syenite contains higher amount of alumina, alkaline oxides $\left(\mathrm{Na}_{2} \mathrm{O}+\mathrm{K}_{2} \mathrm{O}\right)$ and lower amount of $\mathrm{SiO}_{2}$ with respect to feldspars [7]. It is well known that the amount of alkaline oxides is an important component, which determines the viscosity

*corresponding author; e-mail: z.ozturk@nevsehir.edu.tr and amount of glassy phase and also the crystal phases of ceramic bodies. The aim of this study was to compare the thermal behavior of floor tile glazes which contain nepheline-syenite and feldspars (sodium and potassium feldspars). For this purpose several formulations were prepared with industrial raw materials. After applying the glazes on bodies, the compositions were fired in industrial floor tile kiln. Thermal behavior of glazes was measured by hot stage microscope and the crystalline phases were identified by X-ray diffraction. Color properties and glossiness were measured for comparing the aesthetic characteristics.

\section{Experimental}

Four floor tile glaze compositions were prepared using nepheline syenite, potassium and sodium feldspars. These compositions were designed using standard opaque Ca frit, zinc oxide, kaolin, dolomite and the above fluxing agents. Raw materials used in glaze preparation were provided by Yurtbay Ceramic Factory (Turkey). The chemical composition determined by wet chemical analysis is given in Table I. The change of modified raw materials in recipes is demonstrated in Table II. The total amount of alkaline oxide of the nepheline syenite especially $\mathrm{Na}_{2} \mathrm{O}$ and $\mathrm{K}_{2} \mathrm{O}$ shows the highest concentration among the other fluxing agents. Each batch was wetground in a pot mill for a duration of 13-15 min, till the residue on 200 mesh sieve was reduced to less than 1.5 wt.\%. The slip thus prepared was applied on previously fired without engobe of floor tiles, with a ragle. Then the glazed tiles were oven-dried till the moisture content was reduced to less than $0.5 \%$. The dried samples were fast fired in a roller furnace under industrial conditions at $1195{ }^{\circ} \mathrm{C} / 32 \mathrm{~min}$. 
Chemical analysis of the raw materials (wt.\%).

TABLE I

\begin{tabular}{c|c|c|c|c|c|c|c|c|c|c}
\hline \hline $\begin{array}{c}\text { Raw } \\
\text { Materials }\end{array}$ & $\mathrm{L.O.I}$ & $\mathrm{SiO}_{2}$ & $\mathrm{Al}_{2} \mathrm{O}_{3}+\mathrm{TiO}_{2}$ & $\mathrm{Fe}_{2} \mathrm{O}_{3}$ & $\mathrm{CaO}$ & $\mathrm{MgO}$ & $\mathrm{Na}_{2} \mathrm{O}$ & $\mathrm{K}_{2} \mathrm{O}$ & $\mathrm{ZnO}$ & $\begin{array}{c}\sum \text { alkaline } \\
\text { oxides }\end{array}$ \\
\hline $\begin{array}{c}\text { Sodium } \\
\text { feldspar }\end{array}$ & 0.22 & 70.08 & 18.95 & 0.08 & 0.65 & 0.18 & 9.62 & 0.18 & - & 10.63 \\
\hline $\begin{array}{c}\text { Potassium } \\
\text { feldspar }\end{array}$ & 0.53 & 66.67 & 19.51 & 0.12 & 0.27 & 0.18 & 2.98 & 9.74 & - & 13.17 \\
\hline $\begin{array}{c}\text { Nepheline } \\
\text { Syenite }\end{array}$ & 0.53 & 59.80 & 24.08 & 0.10 & 0.54 & 0.54 & 9.99 & 4.44 & - & 15.51 \\
\hline Ca frit & - & 49.25 & 20.4 & - & 19.40 & 7.46 & 0.5 & 1.0 & - & - \\
\hline $\begin{array}{c}\text { Zinc } \\
\text { oxide }\end{array}$ & - & - & - & - & - & - & - & - & 99.99 & - \\
\hline Kaolin & 12.50 & 49.00 & 37.00 & - & - & - & - & 1.42 & - & - \\
\hline Dolomite & 30.85 & 0.71 & - & - & 47.15 & 21.15 & 0.13 & - & - & -
\end{tabular}

L.O.I: Loss of ignition

In order to find out the glaze behavior under heat treatment it was studied with a hot stage microscope (Misura 332 ODHT-HSM 1600/80). The following temperatures were determined as sintering, softening, sphere, halfsphere and melting. The hot stage microscope regime was performed in powder form, to $400{ }^{\circ} \mathrm{C}$ using a heating rate of $50^{\circ} \mathrm{C} / \mathrm{min}$, then with heating rate of $10^{\circ} / \mathrm{min}$ from $400{ }^{\circ} \mathrm{C}$ to $1400^{\circ} \mathrm{C}$. The color values and gloss parameters in $60^{\circ}$ resulting fired samples were measured with the aid of a chromo-meter and gloss meter (Minolta CR-300 Colormeter and Minolta Gloss 268). In order to find out the phase transitions of the glazed floor tiles after sintering, X-ray diffraction (XRD) analysis (Rigaku Rint 2000) was carried out.

TABLE II

Amount of modified raw materials in recipes (wt.\%).

\begin{tabular}{c|c|c|c}
\hline \hline $\begin{array}{c}\text { Sample } \\
\text { Sample }\end{array}$ & $\begin{array}{c}\text { Sodium } \\
\text { Feldspar }\end{array}$ & $\begin{array}{c}\text { Potassium } \\
\text { Feldspar }\end{array}$ & $\begin{array}{c}\text { Nepheline } \\
\text { Syenite }\end{array}$ \\
\hline S.1 & - & 48 & - \\
\hline S.2 & 48 & - & - \\
\hline S.3 & 24 & 24 & - \\
\hline S.4 & - & - & 48 \\
\hline
\end{tabular}

\section{Results and discussions}

The detailed hot stage microscope results of the glazes are given in Table III. When this Table is examined, it is observed that the S.4 glaze showed lower sintering and softening temperatures than the other glazes. The melting temperature of $\mathrm{S} .4$ glaze composition is by $32^{\circ} \mathrm{C}$ lower than the melting temperature of S.1. This reduction can be explained with the nepheline syenite addition which contains more alkaline-earth oxide and lower silicon dioxide. Esposito et al. [8] explained the lower viscosity of glaze samples with nepheline syenite addition by the lower melting point of nepheline syenite. Salem et al. [3] also determined that using nepheline syenite caused a lower viscosity of liquid phase in their studies. They have reported that fluxing agent like nepheline syenite should help in enhancing the densification rate of ceramic bodies if glassy phase viscosity decreases with addition fluxing agents. The increase of mobility of glass is observed in $\mathrm{K}_{2} \mathrm{O}$ and $\mathrm{Na}_{2} \mathrm{O}$-containing glazes during firing [9]. Glaze fusibility could be increased at low temperatures by using $\mathrm{Na}_{2} \mathrm{O}$ instead of $\mathrm{K}_{2} \mathrm{O}$ in single fired tile manufacture [10]. Thus, it is seen that $T_{\text {softening }}, T_{\text {melting }}$ of S.2 and S.4 glazes were lower than that of S.1 glaze with the potassium feldspar.

Hot stage microscope analyses of glazes $\left({ }^{\circ} \mathrm{C}\right)$. TABLE III

\begin{tabular}{c|c|c|c|c|c}
\hline \hline Glazes & $T_{\text {Sintering }}$ & $T_{\text {Softening }}$ & $T_{\text {Sphere }}$ & $T_{\text {Half Sphere }}$ & $T_{\text {Melting }}$ \\
\hline S.1 & 1076 & 1156 & 1178 & 1210 & 1256 \\
\hline S.2 & 1116 & 1162 & - & 1202 & 1228 \\
\hline S.3 & 1102 & 1154 & 1184 & 1208 & 1236 \\
\hline S.4 & 1066 & 1132 & - & 1180 & 1224
\end{tabular}

The comparisons of the $L^{*}, a^{*}, b^{*}$ and gloss values of produced glazes are given in Table IV. $L^{*}, a^{*}$ and $b^{*}$ parameters show whiteness, red or green and yellow or blue color tendency, respectively. Das and Dana [11] observed that the whiteness index $\left(L^{*}\right)$ decreases as the body approaches vitrification at higher temperatures in their study. They explained the variation of $L^{*}$ index with the increased intensity of color-forming oxides $\left(\mathrm{Fe}_{2} \mathrm{O}_{3}\right.$ and $\mathrm{TiO}_{2}$ ), present in the raw materials at higher temperatures. For the same reason, glaze with nepheline syenite and potassium feldspar (S.4 and S.1) showed lower $L^{*}$ index, compared to glaze with sodium feldspar (S.2). Furthermore, it was observed that nepheline syenite and potassium feldspar cause rising of $a^{*}$ and $b^{*}$ values, which was expected due to the increasing level of $\mathrm{Fe}_{2} \mathrm{O}_{3}$ content.

When the glossiness of the glazes is compared, the highest glossiness was seen in S.1 glaze with potassium feldspar addition. Pekkan and Karasu [12], explained the lower glossiness of the glazes with the increased ratios in the $\mathrm{Al}_{2} \mathrm{O}_{3} / \sum \mathrm{R}_{2} \mathrm{O}$ and $\mathrm{Al}_{2} \mathrm{O}_{3} / \sum \mathrm{RO}$ in their studies. Therefore, alumina and alkaline oxide content must have to be considered together. For this reason, glaze with potassium feldspar, which has the lower $\mathrm{Al}_{2} \mathrm{O}_{3} /\left(\mathrm{R}_{2} \mathrm{O}+\sum \mathrm{RO}\right)$ ratio (1.47) than the sodium feldspar (1.78) and the nepheline syenite (1.54), showed the highest glossiness. 
Colorimetric coordinates and gloss $\left(60^{\circ}\right)$ values of the glazed tiles.

\begin{tabular}{c|c|c|c|c}
\hline \hline $\begin{array}{c}\text { Glazed floor } \\
\text { tile samples }\end{array}$ & $L^{*}$ & $a^{*}$ & $b^{*}$ & $\beta_{60}$ \\
\hline $\begin{array}{c}\text { S.0 (non-glazed } \\
\text { fired floor tile) }\end{array}$ & 56.13 & 5.51 & 13.14 & - \\
\hline S.1 & 64.74 & 3.32 & 7.50 & 79.2 \\
\hline S.2 & 67.71 & 2.54 & 5.91 & 20.3 \\
\hline S.3 & 66.54 & 2.79 & 6.36 & 39.4 \\
\hline S.4 & 64.20 & 3.08 & 7.47 & 20.2
\end{tabular}

Plagioclase, albite, microcline and quartz were the main crystalline phases detected in the studied glazes (Fig. 1). The lower peak intensity was found in S.1 glaze with potassium feldspar addition. Roughness caused by the crystals appearing at the surface could also cause a decrease in glossiness $[13,14]$. Therefore, lower crystallization could be another reason which caused higher glossiness in glaze S.1 with potassium feldspar addition.

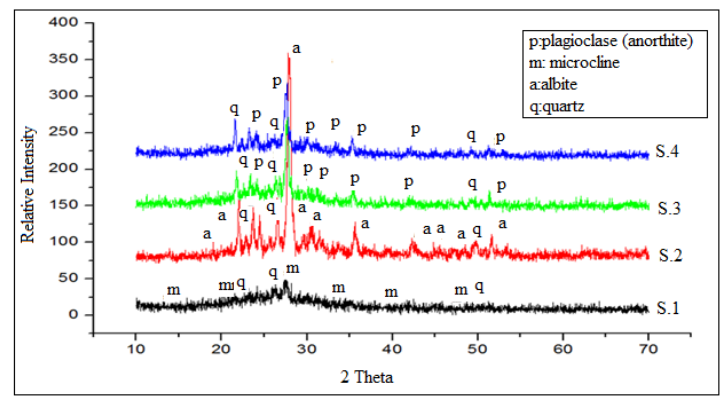

Fig. 1. XRD patterns of ceramic glazes.

In this work plagioclase peak intensity was higher in S.4 glaze with nepheline syenite addition. This result could be explained with the higher alkaline and alumina content of nepheline syenite. Plagioclase formation could be the result of the attraction between glassy phase and Ca based matt frit, dolomite. This phase (i.e. anorthitealbite solid solution) was observed in the alumina rich glazes. Furthermore, the dissolved alkaline earth oxides contributed to the formation of plagioclase crystals [15]. In this work the alkaline oxides and alumina content of nepheline syenite in comparison with potassium feldspar are higher, as seen from Table I.

\section{Conclusions}

In the present study, the possibility of replacing different amount of potassium and sodium feldspars with the same amounts of nepheline-syenite in a floor tile glaze composition was investigated. From the results, the following conclusions were adopted:

- Hot stage microscope results of the studied glazes showed that the nepheline syenite is the most effective feldspar for decreasing the characteristic temperatures $\left(T_{\text {Sintering }}, T_{\text {Softening }}, T_{\text {Sphere }}, T_{\text {Half Sphere }}\right.$, $\left.T_{\text {Melting }}\right)$ because of its higher alkaline oxide content.
- Quartz, albite, microcline and plagioclase were the main crystalline phases observed in the studied glazes. High amount of alkaline earth oxides and alumina content of nepheline syenite was favored the formation of plagioclase.

- S.4 and S.1 glazes with nepheline syenite and potassium feldspar addition respectively showed lower $L^{*}$ value compared to glaze with sodium feldspar addition. The reasons for this are, (i) the $L^{*}$ value decreases as the body approached vitrification at higher temperatures and (ii) in the same time nepheline syenite and potassium feldspar cause rising of $a^{*}$ and $b^{*}$ values, which was expected due to the increasing level of $\mathrm{Fe}_{2} \mathrm{O}_{3}$ content.

- Glaze with potassium feldspar (S.1) which has the lower $\mathrm{Al}_{2} \mathrm{O}_{3} /\left(\mathrm{R}_{2} \mathrm{O}+\sum \mathrm{RO}\right)$ ratio (1.47) than the sodium feldspar (1.78) and the nepheline syenite (1.54) showed the highest glossiness. Lower crystallization detected in glaze S.1 could be another reason to cause higher glossiness in this glaze.

\section{Acknowledgments}

The authors would like to thank Prof. Dr. Alpagut KARA from Anadolu University and the Ceramic Research Centre of Turkey for the research support.

\section{References}

[1] N.F. Zhernovaya, Yu.V. Burchakova, F.E. Zhernovoi, E.V. Miroshnikov, Glass Ceram. 70, 104 (2013).

[2] F.G. Melchiades, B.T. Rego, S.M. Higa, H.J. Alves, A.O. Boshi, J. Eur. Ceram. Soc. 30, 2443 (2010).

[3] A. Salem, S.H. Jazayeri, E. Rastelli, G. Timelli, J. Mater. Process. Tech. 209, 1240 (2009).

[4] F. Matteucci, M. Dondi, G. Guarini, Ceram. Int. 28, 873 (2002).

[5] W.Z. Rogers, Ceram. Eng. Sci. Proc. 24, 272 (2003).

[6] D.M. Ibrahim, E.H. Sallam, A.A. Khalil, S.M.H. Naga, Ceram. Int. 7, 69 (1981).

[7] A. Salem, S.H. Jazayeri, E. Rastelli, G. Timelli, Thermochim. Acta 503-504, 1 (2010).

[8] L. Esposito, A. Salem, A. Tucci, A. Gualtieri, S.H. Jazayeri, Ceram. Int. 31, 233 (2005).

[9] J.R. Taylor, A.C. Bull, Ceramics Glaze Technology, Pergamon Press, New York 1986, p. 22.

[10] E. Bou, A. Moreno, A. Escardino, A. Gozalbo, J. Eur. Ceram. Soc. 27, 1791 (2007).

[11] S.Kr. Das, K. Dana, Thermochim. Acta 406, 199 (2003).

[12] K. Pekkan, B. Karasu, J. Eur. Ceram. Soc. 29, 1571 (2009).

[13] R. Casasola, J.Ma. Rincón, M. Romero, J. Mat. Sci. 47, 553 (2012).

[14] J.L. Amorós, A. Gozalbo, S. Mestre, M.J. Orts, B. Campos, A.J. Ramos, J.F. Aparisi, F.J. Ferrando, M. Paulo, Qualicer, Spain 2006, p. 203.

[15] L.Fröberg, T.Kronberg, L.Hupa, J. Eur. Ceram. Soc. 29, 2153 (2009). 